\title{
Neurokinin-1 receptor activation in globus pallidus
}

\author{
Lei Chen ${ }^{1,2}$, Qiao-Ling Cui 1,2 and Wing-Ho Yung ${ }^{1}$ * \\ 1 School of Biomedical Sciences, Faculty of Medicine, The Chinese University of Hong Kong, Shatin, Hong Kong, China \\ 2 Department of Physiology, Qingdao University, Qingdao, China
}

\author{
Edited by: \\ Ian M. Stanford, Aston University, UK \\ Reviewed by: \\ Steven W. Johnson, Portland Veterans \\ Affairs Medical Center, USA; \\ Oregon Health and Science University, \\ USA \\ Roland S. G. Jones, \\ University of Bath, UK \\ *Correspondence: \\ Wing-Ho Yung, School of Biomedical \\ Sciences, Faculty of Medicine, The \\ Chinese University of Hong Kong, \\ Shatin, Hong Kong, China. \\ e-mail:whyung@cuhk.edu.hk
}

The undecapeptide substance $P$ has been demonstrated to modulate neuronal activity in a number of brain regions by acting on neurokinin-1 receptors. Anatomical studies revealed a moderate level of neurokinin-1 receptor in rat globus pallidus. To determine the electrophysiological effects of neurokinin-1 receptor activation in globus pallidus, whole-cell patch-clamp recordings were performed in the present study. Under current-clamp recordings, neurokinin-1 receptor agonist, [Sar9, Met(O2)11] substance $\mathrm{P}(\mathrm{SM}-\mathrm{SP})$ at $1 \mu \mathrm{M}$, depolarized globus pallidus neurons and increased their firing rate. Consistently, SM-SP induced an inward current under voltageclamp recording. The depolarization evoked by SM-SP persisted in the presence of tetrodotoxin, glutamate and GABA receptor antagonists, indicating its direct postsynaptic effects. The neurokinin-1 receptor antagonist, SR140333B, could block SM-SP-induced depolarization. Further experiments showed that suppression of potassium conductance was the predominant ionic mechanism of SM-SP-induced depolarization. To determine if neurokinin-1 receptor activation exerts any effects on GABAergic and glutamatergic neurotransmission, the action of SM-SP on synaptic currents was studied. SM-SP significantly increased the frequency of spontaneous inhibitory postsynaptic currents, but only induced a transient increase in the frequency of miniature inhibitory postsynaptic currents. No change was observed in both spontaneous and miniature excitatory postsynaptic currents. Based on the direct excitatory effects of SM-SP on pallidal neurons, we hypothesize that neurokinin-1 receptor activation in globus pallidus may be involved in the beneficial effect of substance $P$ in Parkinson's disease.

Keywords: substance $\mathrm{P}$, neurokinin-1 receptor, globus pallidus

\section{INTRODUCTION}

Substance P, a widely distributed undecapeptide, has been established as a neurotransmitter or neuromodulator in central nervous system. By acting on neurokinin-1 receptors (substance $P$ receptors), substance $\mathrm{P}$ has been demonstrated to modulate neuronal activity in a number of brain regions. Experimental and preclinical evidence suggested that substance $P$ is involved in several neurological diseases, including degeneration of human motoneurons (Vacca-Galloway and Steinberger, 1986; Tang et al., 1990; Yung et al., 1992), depression (Santarelli and Saxe, 2003; Czeh et al., 2005), Alzheimer's disease (Rioux and Joyce, 1993; Rosler et al., 2001), Parkinson's disease (Pezzoli et al., 1984; Rioux and Joyce, 1993) and Huntington's disease (Lastres-Becker et al., 2002). In terms of cellular actions, previous electrophysiological studies have demonstrated that substance $\mathrm{P}$ can enhance firing rate and depolarized neurons in several brain areas (Stanfield et al., 1985; Norris et al., 1993; Shirakawa and Moore, 1994; Napier et al., 1995; Minabe et al., 1996; Li and Guyenet, 1997; Wang and Robertson, 1997, 1998; Mitrovic and Napier, 1998; Preston et al., 2000; Bailey et al., 2004). It is therefore generally regarded as an excitatory neurotransmitter or neuromodulator.

Anatomical studies have revealed a high expression level of substance $\mathrm{P}$ and its receptor in the basal ganglia, which is in line with its involvement in basal ganglia motor dysfunctions. Indeed, previous studies have shown that the concentration of substance $\mathrm{P}$ in cerebrospinal fluid and the expression of substance $\mathrm{P}$ or its receptor in striatum are altered in Parkinson's disease (Pezzoli et al.,
1984; Rioux and Joyce, 1993; Betarbet and Greenamyre, 2004). Furthermore, intracerebroventricular administration of substance $P$ increases dopamine content in 6-hydroxydopamine (6-OHDA) lesioned rats (Krasnova et al., 2000), which implicates its potential in the treatment of Parkinson's disease. In addition, substance $\mathrm{P}$ level in striatum is reduced in Huntington's disease (Lastres-Becker et al., 2002). Extracellular recordings have also shown ventral pallidum neurons are excitable by microiontophoretic application of substance $\mathrm{P}$ (Napier et al., 1995). In rat striatum, substance $\mathrm{P}$ has been reported to depolarize cholinergic and somatostatinergic interneurons (Aosaki and Kawaguchi, 1996).

Being a critical component in the basal ganglia, the globus pallidus plays a significant role in mediating movement in health and disease state. It is well known that dopamine depletion leads to hypoactivity and oscillatory activity of globus pallidus neurons which are associated with the hypokinetic symptom and tremor observed in parkinsonism (Albin et al., 1989; Filion and Tremblay, 1991; Chesselet and Delfs, 1996; Wichmann and DeLong, 1996; Bergman et al., 1998; Plenz and Kital, 1999; Magill et al., 2001). Early anatomical studies have demonstrated the presence of both substance $\mathrm{P}$ and its receptors in globus pallidus (Mantyh et al., 1984). In normal rat globus pallidus, substance $P$ immunolabeling is localized in fibers without being expressed in the cell bodies. However, following nigrostriatal lesion, substance $\mathrm{P}$ immunoreactivity can be observed in both fibers and numerous cell bodies of pallidal neurons (Martorana et al., 2003). In contrast to substance P immunolabeling, a moderate level of substance P receptors 
is expressed in rat globus pallidus (Mantyh et al., 1984). Similarly, numerous substance $P$ receptors are observed in human external globus pallidus which exhibits a marked decreasing rostrocaudal gradient (Mounir and Parent, 2002). In Parkinson's disease, there is a reduction in the density of substance $P$ receptors in lateral globus pallidus (Fernandez et al., 1994). Therefore, to fully understand the role of substance $\mathrm{P}$ in basal ganglia under normal and pathological conditions, it is important to determine the actions of substance $\mathrm{P}$ in the globus pallidus. Recently, our previous in vivo extracellular recording and behavioral experiments revealed that substance $\mathrm{P}$ can excite globus pallidus neuron (Cui et al., 2007). To further identify the cellular mechanisms of substance P-induced excitation in globus pallidus, whole-cell patch-clamp recording was employed in the present experiment to address this question.

\section{MATERIALS AND METHODS ELECTROPHYSIOLOGICAL RECORDINGS In vitro slice preparation}

Sprague-Dawley rats aged 12-14 days were used for the preparation of acute brain slices. The animals were sacrificed by decapitation. The brains were immediately removed and placed in ice-cold artificial cerebrospinal fluid (ACSF) of the following composition (in $\mathrm{mM}$ ): $\mathrm{NaCl} 125, \mathrm{KCl} 4.0, \mathrm{MgSO}_{4} 1.2, \mathrm{CaCl}_{2} 2.5, \mathrm{KH}_{2} \mathrm{PO}_{4} 1.2$, glucose 11 and $\mathrm{NaHCO}_{3} 26$, which was continuously bubbled with $95 \% \mathrm{O}_{2}$ and $5 \% \mathrm{CO}_{2}$. Hemi-coronal slices $(250 \mu \mathrm{m})$ containing the globus pallidus were cut using a vibrating microtome (Campden Instruments). After equilibration in ACSF for at least $30 \mathrm{~min}$, the slices were transferred to a small volume chamber mounted on an upright microscope (Zeiss Axioskop), and superfused with ACSF at a rate of $1.5-2.0 \mathrm{ml} / \mathrm{min}$ maintained at a temperature of $34 \pm 1^{\circ} \mathrm{C}$. Neuronal soma and proximal dendrites of neurons were directly visualized by a combination of differential interference contrast optics and contrast-enhanced video microscopy. All procedures were approved by the Animal Research Ethics Committee, the Chinese University of Hong Kong.

\section{Whole-cell patch-clamp recordings}

Whole-cell patch-clamp recordings from globus pallidus neurons were obtained using a patch-clamp amplifier (LM/PCA, List Medical). Whole-cell pipettes (P-97, Sutter Instrument) typically had a resistance of 3-4 M $\Omega$. For current-clamp recording and some voltage-clamp experiments, the pipettes were filled with an internal solution of the following composition (in $\mathrm{mM}$ ): $\mathrm{KMeSO}_{4} 130$, $\mathrm{KCl}$ 10, HEPES 10, EGTA 1, $\mathrm{MgCl}_{2} 2$, Mg-ATP 2, $\mathrm{Na}_{3}$-GTP 0.4 and the $\mathrm{pH}$ was adjusted to 7.25-7.30 with $1 \mathrm{M} \mathrm{KOH}$. $\mathrm{MeSO}_{4}$, rather than gluconate, was used to substitute $\mathrm{Cl}^{-}$because gluconate had been reported to inhibit hyperpolarization-activated non-selective current and calcium activated potassium current (Velumian et al., 1997) that may alter the electrophysiological properties and the action of substance $\mathrm{P}$ in globus pallidus. In order to observe the $\mathrm{GABA}_{\mathrm{A}}$ receptor-mediated synaptic current, the internal solution containing (in mM): $\mathrm{KCl} 140$, HEPES 10, EGTA 1, $\mathrm{MgCl}_{2} 2, \mathrm{Na}_{2}$ ATP 2 and Tris GTP 0.4 was used. The inclusion of $140 \mathrm{mM}$ of $\mathrm{KCl}$ in the recording pipettes reversed the polarity of the currents from outward to inward and enhanced their detection. Monitoring through a television connected to the camera, a pipette was placed on the soma of a pallidal neuron and conventional whole-cell recording was made. Normally no series resistance compensation was applied but the cell was rejected if the series resistance increased significantly $(>20 \%)$ during recording. The current signals were filtered at $3 \mathrm{kHz}$. On- or off-line digitization $(10 \mathrm{kHz})$ was made via the Digidata-pClamp system (Axon Instruments).

\section{ANALYSIS OF CURRENT- AND VOLTAGE DATA}

Membrane potential and current data measurements and analysis were performed with Clampfit 8.1. Computer files containing information of synaptic currents were analyzed by Minianalysis program (Synaptosoft, version 6), which automatically generates various parameters including the time of occurrence, peak amplitude and kinetics. Statistical comparison of two cumulative probabilities was based on the Kolmogorov-Smirnov test.

\section{IMMUNOHISTOCHEMISTRY}

Sprague-Dawley rats aged 12-14 days were deeply anesthetized with urethane and perfused transcardially with normal saline followed by $4 \%$ paraformaldehyde in $0.1 \mathrm{M}$ phosphate buffer $(\mathrm{PB}$, $\mathrm{pH}$ 7.4). Then the brains were removed and postfixed with $4 \%$ paraformaldehyde for $6 \mathrm{~h}$, after which they were transferred into $30 \%$ sucrose in $0.1 \mathrm{M} \mathrm{PBS}\left(4^{\circ} \mathrm{C}\right)$ until they sank. Coronal cryotome sections $(18 \mu \mathrm{m})$ were cut through the globus pallidus and collected on poly-L-lysine-coated slides. After overnight drying at room temperature, the sections were treated with $0.3 \% \mathrm{H}_{2} \mathrm{O}_{2}$ in methanol for $15 \mathrm{~min}$ to inactivate non-specific peroxidase reactions. After rinsing in PBS three times for $15 \mathrm{~min}$, the sections were blocked in 5\% normal goat serum at room temperature for half an hour. The primary antibody against substance $\mathrm{P}$ receptor (1:100; a gift from Shigemoto Ryuichi) diluted in antibody diluent (Maixin-Bio, China) was then applied and incubated at $4^{\circ} \mathrm{C}$ overnight. After repeated washing, the sections were incubated in Post-blocking (Maixin-Bio, China) for $20 \mathrm{~min}$ at room temperature, rinsed again and incubated for a further $30 \mathrm{~min}$ in poly-HRP Anti-Ms/Rb IgG (Maixin-Bio, China) at room temperature. After washing, the immunoreactive sites were visualized by incubation in $0.05 \% 3,3^{\prime}$-diaminobenzidine tetrahydrochloride in $0.1 \mathrm{M}$ Tris buffer. The reaction was stopped after 3-4 min by several washes in Tris buffer. Afterwards, the sections were rinsed, dehydrated, cleared in xylene and coverslipped. The specificity of immunolabelling was demonstrated by the absence of labelling for substance $P$ receptor when the primary antibody was omitted.

\section{DRUGS AND STATISTICS}

$\left[\right.$ Sar $\left.^{9}, \quad \operatorname{Met}\left(\mathrm{O}_{2}\right)^{11}\right] \quad$ substance $\mathrm{P} \quad(\mathrm{SM}-\mathrm{SP}), \quad(2 S)-3-[[(1 S)-$ 1 -(3,4-dichlorophenyl)ethyl] a mino-2-hydroxylpropyl] (phenylmethyl)phosphinic acid (CGP55845) and (RS)- $\alpha$-ethyl-4carboxyphenylglycine (E4CPG) were obtained from Tocris. \pm -2Amino-5-phosphonopentanoic acid (AP5), 6-cyano-7-nitroquino xaline-2,3-dione (CNQX), bicuculline, tetrodotoxin (TTX), 4-aminopyridine (4-AP), tetraethylammonium (TEA) and barium chloride dihydrate were obtained from Sigma/RBI. SR140333B was kindly provided by Sanofi-Aventis-Chilly-Mazarin.

The data are expressed as means \pm SEM. Paired $t$-test was used to compare the difference before and after drug application, Un-paired $t$-test was used to compare the difference between different treatment groups. The level of significance was set at a $P$ value of 0.05 . 


\section{RESULTS}

\section{SM-SP DEPOLARIZED AND EXCITED GLOBUS PALLIDUS NEURONS}

Under current-clamp recordings, application of $1 \mu \mathrm{M}$ SM-SP to the superfusion medium significantly increased the firing rate of spontaneously active globus pallidus neurons (control $10.9 \pm 2.1 \mathrm{~Hz}, S M-S P 16.3 \pm 2.6 \mathrm{~Hz}$, wash $11.3 \pm 2.0 \mathrm{~Hz}$, $n=7, P<0.01$; Figure 1A). In some cells in which the firing was suppressed by injecting a hyperpolarizing current, SM-SP could induce firing in a reversible manner. There was clear desensitization of the response to SM-SP. In six cells examined, a second application of SM-SP with an interval of $10 \mathrm{~min}$ generated a response which was $62.7 \pm 8.3 \%$ of the first response. Therefore, in subsequent experiments, only one dose of SM-SP was used in one cell per slice. To determine whether SM-SPinduced excitation is independent of presynaptic firing, TTX was used to block action potential generation in the neurons. In the presence of $0.5 \mu \mathrm{M}$ TTX, SM-SP induced a significant membrane depolarization $(7.8 \pm 1.8 \mathrm{mV}, n=12, P<0.01$; Figure 1B). Consistent with the current-clamp observation, when the cells were voltage-clamped at $-70 \mathrm{mV}, 1 \mu \mathrm{M}$ SM-SP induced a small inward current of $34.2 \pm 1.9 \mathrm{pA}$ in the presence of $0.5 \mu \mathrm{M}$ TTX $(n=12$; Figure 1C).

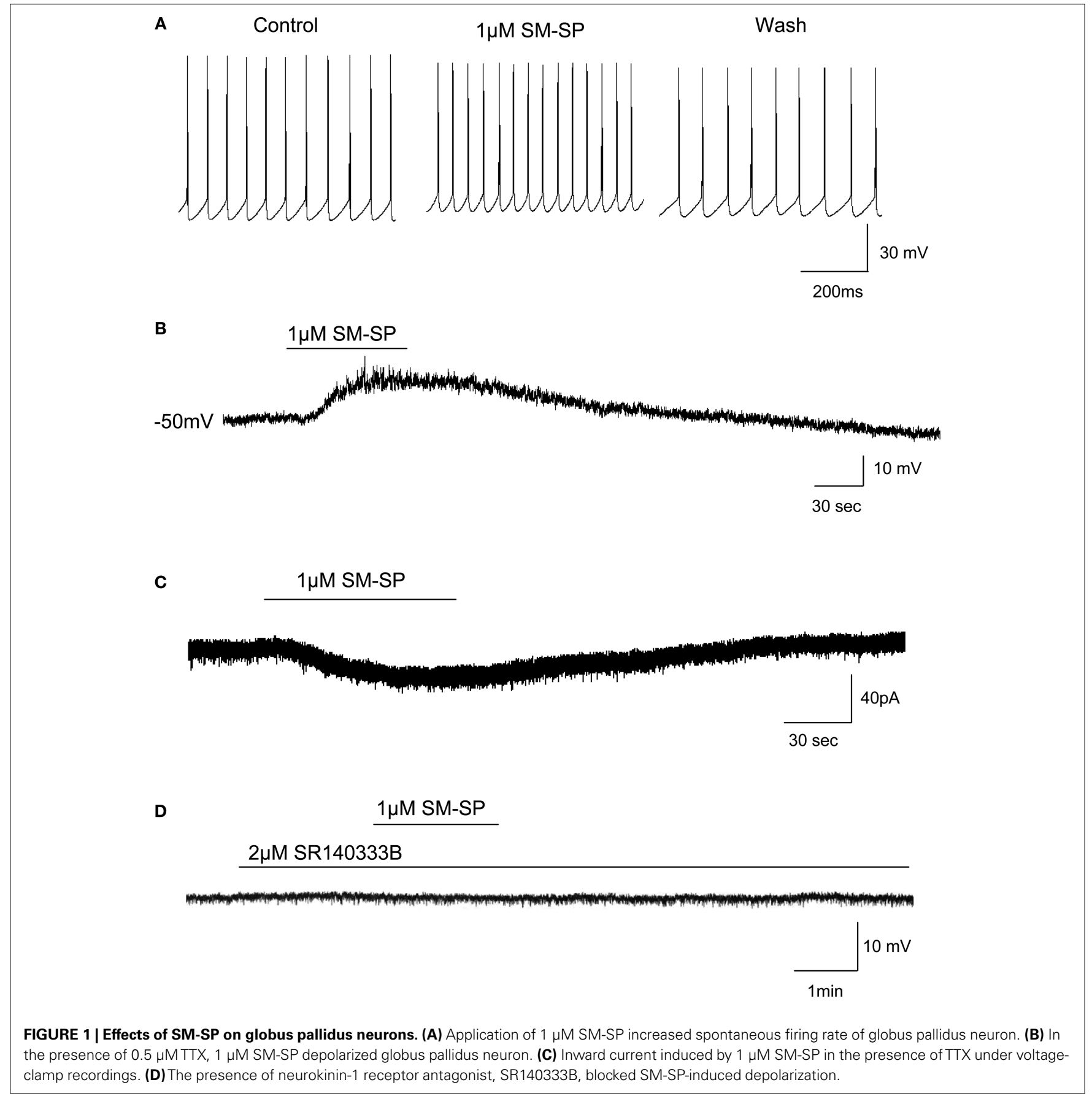




\section{SYNAPTIC TRANSMISSION WAS NOT INVOLVED IN SM-SP-INDUCED DEPOLARIZATION}

It has been reported that substance $P$ could affect the release of glutamate and GABA from nerve terminals. To eliminate the possible involvement of glutamate or GABA release at a presynaptic site, in addition to TTX, ionotropic glutamate receptor antagonists CNQX $(20 \mu \mathrm{M})$ and AP5 $(50 \mu \mathrm{M})$, group I and group II metabotropic glutamate receptor antagonist E4CPG $(300 \mu \mathrm{M}), \mathrm{GABA}_{\mathrm{A}}$ receptor antagonist bicuculline $(10 \mu \mathrm{M})$ and $\mathrm{GABA}_{\mathrm{B}}$ receptor antagonist CGP55845 $(2 \mu \mathrm{M})$ were applied to the perfusion medium. In these cases, SM-SP still depolarized globus pallidus neurons $(6.2 \pm 1.4 \mathrm{mV}$, $n=5, P>0.05$ compared to SM-SP with TTX alone), suggesting that the depolarization was induced by a direct postsynaptic action.

\section{DEPOLARIZATION INDUCED BY SM-SP WAS MEDIATED BY NEUROKININ-1 RECEPTORS}

We used a selective neurokinin-1 receptor antagonist, SR140333B to verify the type of neurokinin receptors mediating SM-SPinduced depolarization. In the presence of TTX, pretreatment of $2 \mu \mathrm{M}$ SR140333B could block the depolarization induced by SM-SP $(0.6 \pm 0.3 \mathrm{mV}, n=8, P<0.01$ compared with SM-SP with TTX alone; Figure 1D). The antagonist itself had no effect on the membrane potential.

\section{DOSE-DEPENDENT EFFECT OF SM-SP}

The dose-dependency of the effect of SM-SP was examined. Only one dose per cell was examined to avoid the complication of receptor desensitization. As can be seen in Figure 2, the does-response curve was bell-shaped, with the biggest effect observed at an SM-SP concentration of 0.3 and $1.0 \mu \mathrm{M}$.

\section{IONIC MECHANISMS OF ACTION OF SM-SP}

To determine the ionic mechanisms of SM-SP-induced depolarization, we monitored the conductance change of pallidal neurons by delivering negative current pulses (100 pA, $100 \mathrm{~ms})$ to the neurons

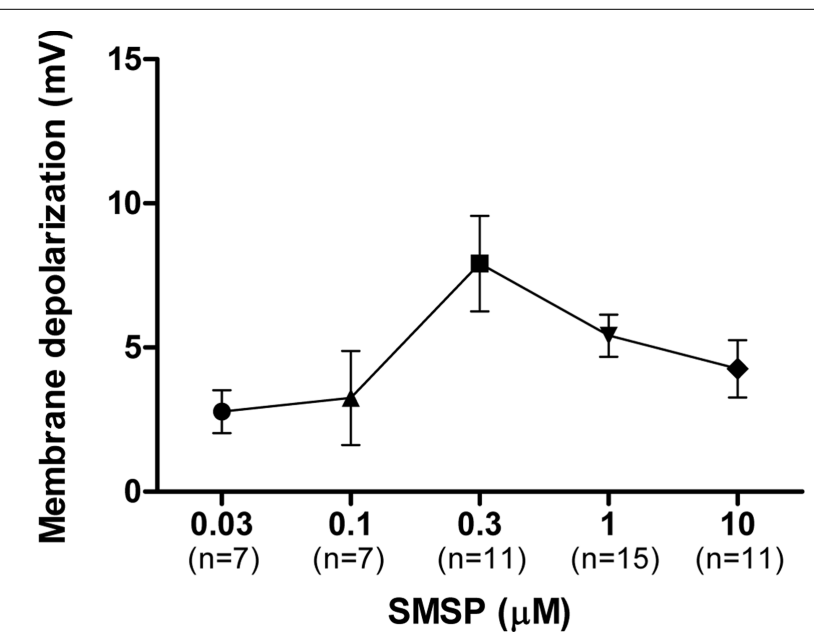

FIGURE 2 | Dose-dependent effects of SM-SP. The magnitude of membrane depolarization of globus pallidus neurons was dependent of the concentration of SM-SP. $n$ indicates the number of cells studied. Only one dose of SM-SP was tested on one cell. at $0.5 \mathrm{~Hz}$. In 12 neurons recorded, SM-SP-induced membrane depolarization $(8.0 \pm 1.1 \mathrm{mV})$ was associated with a small but clear increase in membrane resistance $(17.1 \pm 3.3 \%, n=12$; Figure 3A). To confirm the involvement of potassium conductance in mediating the actions of SM-SP in globus pallidus, the effects of potassium channel blockers were studied. In the presence of $1 \mathrm{mM}$ barium, $30 \mathrm{mM}$ TEA and $5 \mathrm{mM}$ 4-AP, SM-SP-induced inward current was attenuated significantly $(1.9 \pm 1.3 \mathrm{pA}, n=9, P<0.001$ compared to SM-SP with TTX alone; Figure 3B). To evaluate the reversal potentials of SM-SP-induced conductance, the current-voltage relationship in the presence of TTX was determined. The mean value of reversal potential was $-95.0 \pm 2.6 \mathrm{mV}$ in the six cells studied, which is reasonably close to the potassium equilibrium potential. A typical I-V plot is shown in Figure 3C.

\section{EFFECTS OF SM-SP ON SYNAPTIC CURRENTS}

\section{SM-SP enhanced spontaneous inhibitory postsynaptic currents}

To observe the effects of substance $\mathrm{P}$ on spontaneous inhibitory postsynaptic currents (sIPSCs), the cells were held at $-70 \mathrm{mV}$. $20 \mu \mathrm{M}$ CNQX and $50 \mu \mathrm{M}$ AP5 were used in the superfusion solution to block ionotropic glutamate receptor-mediated synaptic currents. The remaining currents were sensitive to $10 \mu \mathrm{M}$ bicuculline confirming their GABAergic nature. When $1 \mu \mathrm{M}$ SM-SP was applied to the superfusion medium, the frequency of sIPSCs was increased significantly (control $5.6 \pm 1.0 \mathrm{~Hz}, \mathrm{SM}-\mathrm{SP} 10.0 \pm 1.6 \mathrm{~Hz}$, $n=8, P<0.01)$. This effect was partially reversible when SM-SP was removed (wash: $6.9 \pm 1.1 \mathrm{~Hz}$ ). In addition to its effect on the frequency, SM-SP increased the amplitude of sIPSCs in some of the cells tested although there was no significant difference when the data were pooled from all cells (control 86.9 $\pm 9.9 \mathrm{pA}, \mathrm{SM}-\mathrm{SP}$ $102.5 \pm 8.9 \mathrm{pA}, n=8, P>0.05$; Figure 4). SM-SP had no significant effect on the decay time and rise time of sIPSCs.

The effects of SM-SP on miniature inhibitory postsynaptic currents (mIPSCs) were examined in the presence of $0.5 \mu \mathrm{M}$ TTX. As shown in Figure 5, $1 \mu \mathrm{M}$ SM-SP induced a transient bursting-like increase of mIPSCs in 8 out of 12 cells recorded. The properties of the bursting-like increase were variable, which appeared from 1-4 min after SM-SP application and repeated two to four times. Usually each bursting-like increase lasted less than $30 \mathrm{~s}$. However, if the data were analyzed by excluding the bursts, SM-SP did not alter both the frequency (control $3.1 \pm 0.6 \mathrm{~Hz}, \mathrm{SM}-\mathrm{SP} 3.0 \pm 0.6 \mathrm{~Hz}$, $n=12, P>0.05$ ) and amplitude (control 86.4 $\pm 6.2 \mathrm{pA}, \mathrm{SM}-\mathrm{SP}$ $82.1 \pm 6.3 \mathrm{pA}, n=12, P>0.05)$ of mIPSCs.

\section{Lack of effect of SM-SP on excitatory postsynaptic currents}

To observe the effects of substance $\mathrm{P}$ on spontaneous excitatory postsynaptic currents (sEPSCs), parasagittal slices containing both globus pallidus and subthalamic nucleus were cut. Bicuculline of $10 \mu \mathrm{M}$ was used to block $\mathrm{GABA}_{\mathrm{A}}$ receptor-mediated inhibitory synaptic currents. The remaining currents were sensitive to $20 \mu \mathrm{M}$ CNQX and $50 \mu \mathrm{M}$ AP5, confirming their glutamatergic nature. In contrast to its action on sIPSCs, $1 \mu \mathrm{M}$ SM-SP did not induce any change in the frequency (control $0.83 \pm 0.29 \mathrm{~Hz}, \mathrm{SM}$ SP $0.76 \pm 0.15 \mathrm{~Hz}, n=5, P>0.05$ ) and the amplitude (control $23.8 \pm 1.6 \mathrm{pA}, \mathrm{SM}-\mathrm{SP} 23.6 \pm 2.1 \mathrm{pA}, P>0.05)$ of the sEPSCs. We further isolated miniature EPSCs (mEPSCs) by including $0.5 \mu \mathrm{M}$ TTX. Similar to its effects on sEPSCs, SM-SP did not alter the 


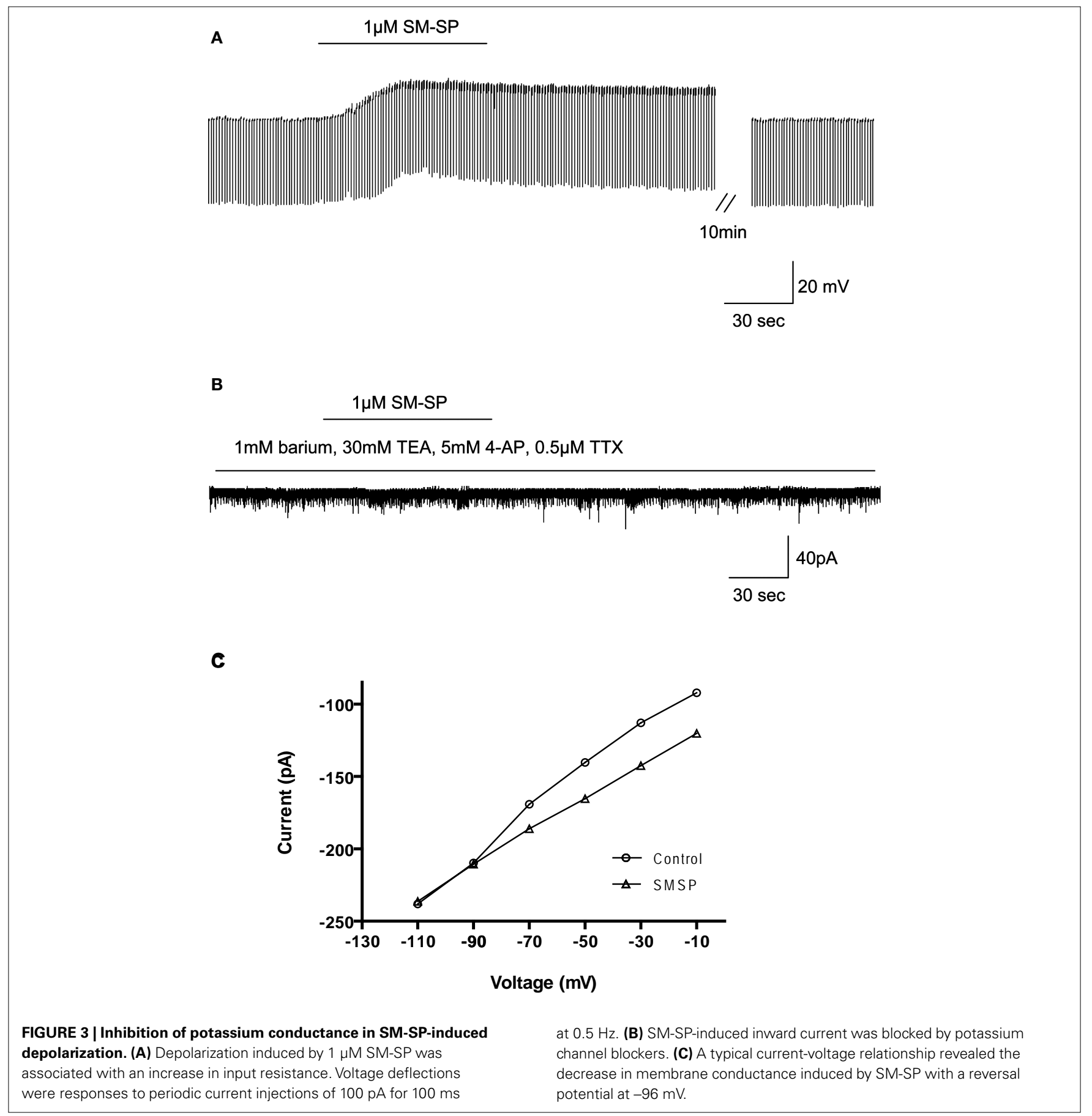

frequency (control $0.50 \pm 0.07 \mathrm{~Hz}, \mathrm{SM}-\mathrm{SP} 0.49 \pm 0.07 \mathrm{~Hz}, n=5$, $P>0.05$ ) and the amplitude (control $23.3 \pm 2.4 \mathrm{pA}$, SM-SP $24.0 \pm 5.4 \mathrm{pA}, P>0.05)$ of mEPSCs.

\section{LOCALIZATION OF SUBSTANCE P RECEPTOR IN RAT GLOBUS PALLIDUS}

The existence of substance $P$ receptor in globus pallidus in our test animals was confirmed by immunohistochemistry. As shown in Figure 6A, in rats aged 14 days, a large number of substance $\mathrm{P}$ receptor immunoreactive neurons were found in globus pallidus. Most of these neurons were multipolar or fusiform in shape, and both the soma and dendrites were positively stained. Immunoreactive punctates were found predominately along the membrane (Figure 6B).

\section{DISCUSSION}

The aim of this study was to determine the cellular action of substance $\mathrm{P}$ in the globus pallidus. We found that the neurokinin-1 receptor agonist, SM-SP, depolarized globus pallidus neurons. This excitatory action was a direct postsynaptic effect because it persisted in the presence of TTX. Previous studies in other brain areas 


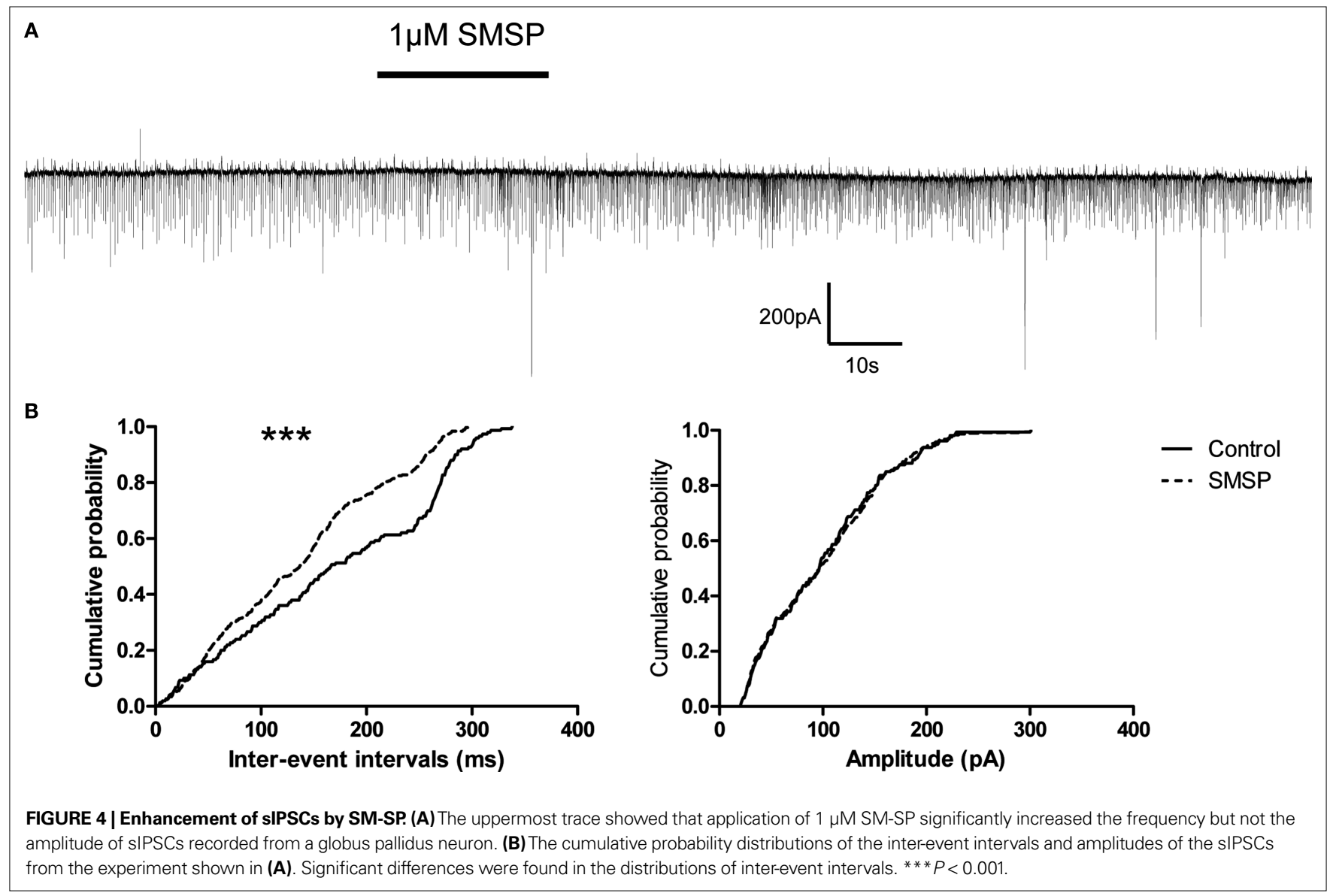

have revealed that substance $\mathrm{P}$ administration affected the release of other neurotransmitters, including glutamate and GABA (Stacey et al., 2002a,b; Bailey et al., 2004; Vergnano et al., 2004). However, the SM-SP-induced depolarization we observed was insensitive to the ionotropic and metabotropic glutamate and GABA receptor antagonists, suggesting the presence of functional postsynaptic neurokinin-1 receptor on pallidal neurons. The present study showed that pretreatment with a selective neurokinin-1 receptor antagonist, SR140333B, can block SM-SP-induced depolarization. Our previous in vivo extracellular recordings showed that SR140333B decreased the spontaneous firing rate in some pallidal neurons, indicating an involvement of endogenous substance P system in modulating electrical activity of pallidal neurons (Cui et al., 2007). However, the data reported here revealed that, under the present in vitro condition, neurokinin-1 receptor antagonist had no effect on the membrane properties, suggesting that there was no tonic action of neurokinin-1 receptor on pallidal neurons. The dose-response relationship of the effect of SM-SP is bell-shaped, with a maximum response observed at 0.3 and $1 \mu \mathrm{M}$ of the agonist. Interestingly, such a bell-shaped doseresponse relationship has also been found in our previous in vivo study (Cui et al., 2007) and other studies (e.g. Khan et al., 1996; de Araujo et al., 1998). It is possible that a rapid desensitization of the receptor underlie the reduced responses at high doses.

Previous studies revealed two major ionic mechanisms underlying substance P-induced depolarization. In most neurons, inhibition of potassium conductance was the predominant ionic mechanism of substance P-induced depolarization, which can be found in nucleus tractus solitarius (Bailey et al., 2004), hypoglossal motoneuron (Yasuda et al., 2001), phrenic motoneuron (Ptak et al., 2000). In other regions, an additional increase of a cation conductance has been reported (Shen and North, 1992; Wang and Robertson, 1998). However, the enhancement of a cation current accounted for substance P-induced depolarization in neostriatal cholinergic neurons (Aosaki and Kawaguchi, 1996; Bell et al., 1998). The present studies on membrane conductance and reversal potential revealed that neurokinin-1 receptor activation induced depolarization was mediated by the closing of potassium channels which were active around resting membrane potential. Further experiment using potassium channel blockers confirmed the involvement of potassium channel.

Although most substance $\mathrm{P}$ receptors are localized at postsynaptic cell bodies and dendrites, immunocytochemical labeling at subcellular level also revealed the localization of substance $\mathrm{P}$ receptors at presynaptic terminals in several brain regions (Jakab and Goldman-Rakic, 1996; Barbaresi, 1998). In striatum, substance $\mathrm{P}$ receptor localized at presynaptic elements forming both asymmetric and symmetric synapses, which indicated that substance P may modulate excitatory and inhibitory neurotransmission acting presynaptically (Jakab and Goldman-Rakic, 1996). Electrophysiological studies have shown that activation of neurokinin-1 receptors increased mIPSCs in nucleus tractus solitarius, amygdala and some lamina II neurons, suggesting the functional 


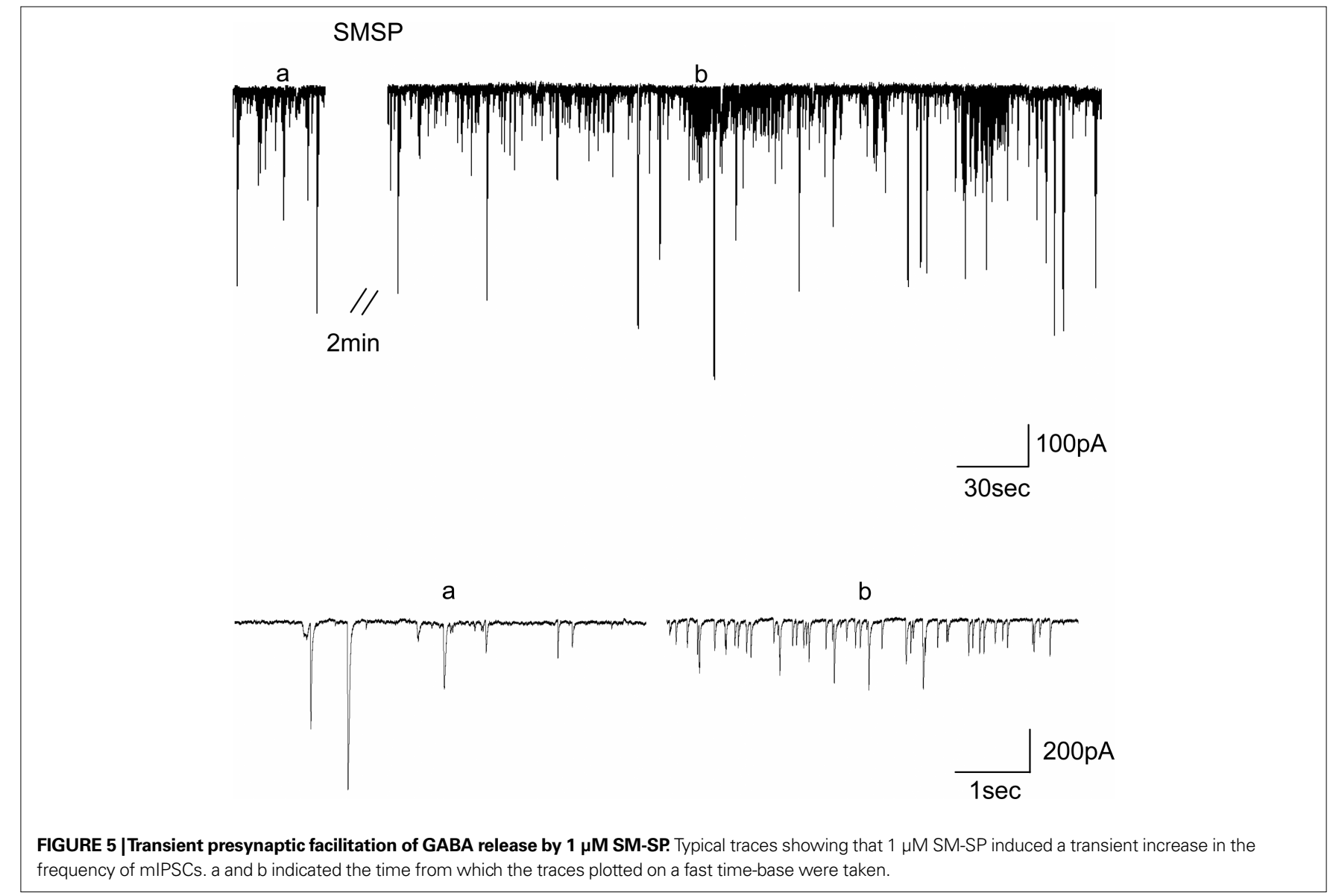

presynaptic neurokinin-1 receptors on GABAergic terminals (Maubach et al., 2001; Bailey et al., 2004; Vergnano et al., 2004). The present experiments revealed that SM-SP induced a transient increase in mIPSCs frequency, which suggested that there exist functional presynaptic neurokinin-1 receptors at GABAergic terminals. Previous studies in various brain regions suggest that activation of glutamate release is a common mechanism of neurokinin-1 receptor activation (e.g. Liu et al., 2002; Stacey et al., 2002b; Bailey et al., 2004). But we did not observe a similar effect in our preparation. However, the developmental stage of the animals tested may underlie the lack of response, which may be more apparent in more mature animals.

The present experiments showing that SM-SP strongly facilitated sIPSCs revealed that SM-SP increased GABA release either at the level of the presynaptic neuronal soma or at the terminal. Because SM-SP only induced a weak and transient increase in action potential independent GABA release, we hypothesize that the excitation of presynaptic neuronal soma is the principal factor. As most striatal neurons are quiescent (Chevalier and Deniau, 1990), the facilitation on sIPSCs observed in the present studies is consistent with the scenario that excitation of pallidal neurons resulted in action potential dependent GABA release from their collaterals. However, since substance $\mathrm{P}$ also exerted both excitatory and inhibitory actions on striatal projection neurons (Galarraga et al., 1999), we cannot rule out the possibility of increased GABA release from striatum. Morphological and electrophysiological studies have revealed that subthalamic nucleus is the major glutamatergic input onto the globus pallidus. Although parasagittal slices were used to keep the subthalamic-pallidal innervation as intact as possible, SM-SP had no significant effect on sEPSCs which suggested that neurokinin-1 receptor activation may not change the excitability of subthalamic nucleus. In addition, the lack of effect of SM-SP on mEPSCs indicated no functional presynaptic neurokinin-1 receptor at glutamatergic terminals. However, up to now, no morphological studies have provided any information about the expression of substance $P$ receptor in subthalamic nucleus as well as subthalamicpallidal pathway.

Previous studies have demonstrated that substance P in basal ganglia plays an important role in the pathophysiology of Parkinson's disease. In parkinsonian patient and 6-OHDA or MPTP treated animal model, substance $P$ mRNA and immunoreactivity in caudatoputamen and substantia nigra was reduced significantly (Taylor et al., 1992; Jenner, 1995; Perez-Otano et al., 1995; Fernandez et al., 1996; Salin et al., 1996; De Ceballos and Lopez-Lozano, 1999). A reduction of substance $P$ receptors in the putamen and lateral globus pallidus has also been observed in Parkinson's disease (Fernandez et al., 1994). These results indicated that the reduction of substance P-ergic system in basal ganglia may be involved in the etiology of Parkinson's disease. Therefore, it has been hypothesized that manipulation of substance P-ergic system may have therapeutic effects in the treatment of Parkinson's disease. Indeed, in animal model of Parkinson's disease, it has been shown that pre- or post-treatment 


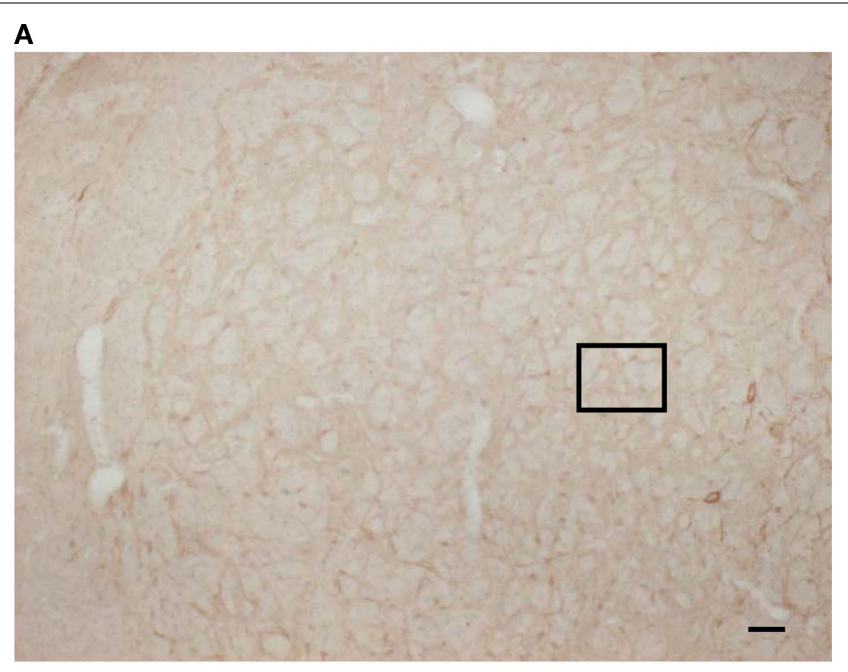

B

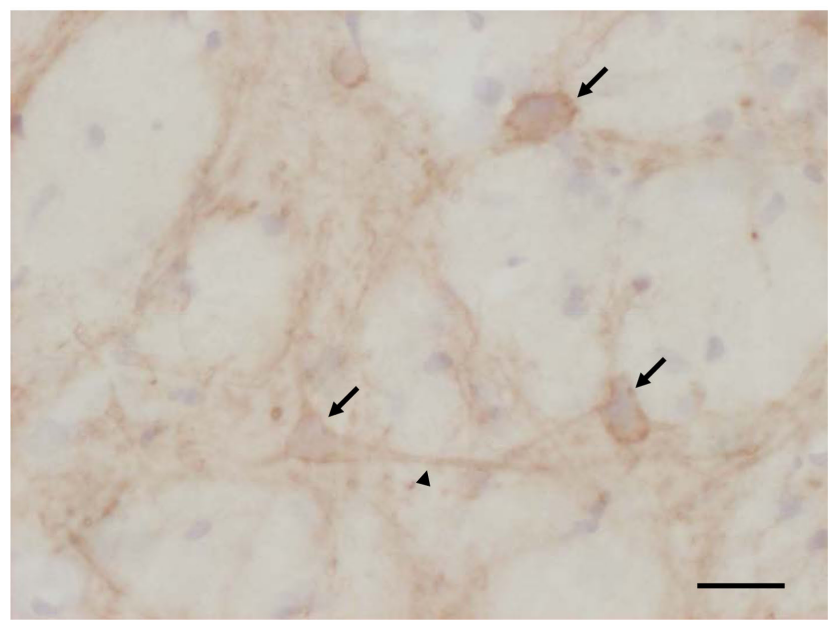

FIGURE 6 | Expression of substance $P$ receptors in globus pallidus of rat aged 14 days. (A) Substance $P$ receptors were moderately expressed by rat globus pallidus neurons. (B) High-magnification photomicrograph shows that substance $P$ receptor immunoreactive neurons were either multipolar or fusiform in shape, and that immunoreactivity was observed predominately along the membrane of both the soma (arrows) and dendrites (arrowheads) of rat globus pallidus neurons. Scale bars: $100 \mu \mathrm{m}$ (A); $25 \mu \mathrm{m}$ (B).

with substance $\mathrm{P}$ or its C-terminal can promote functional recovery in partial nigrostriatal dopamine lesions (Mattioli et al., 1992; Nikolaus et al., 1997, 1999). However, up to now, the reasons for substance P-induced neuroprotection for Parkinson's disease are unclear. Substance P has been shown to enhance neural growth (Iwasaki et al., 1989) and protect striatal neuron via its counteraction to glutamate-excitotoxicity (Sanberg et al., 1993). Consistently, both peripheral and central administration of substance $\mathrm{P}$ can increase dopamine levels in striatum and nucleus accumbens (Barnes et al., 1990; Reid et al., 1990; Boix et al., 1992; Krasnova et al., 2000). It is well known that the hypoactivity of globus pallidus leads to akinesia observed in Parkinson's disease. Therefore, excitation induced by activation of neurokinin receptor in globus pallidus could be beneficial to Parkinson's disease symptoms. Consistent with this idea, morphological studies indicated that lesion of the nigrostriatal pathway increased the expression of substance $\mathrm{P}$ immunoreactivity in numerous pallidal cell bodies (Martorana et al., 2003), which may reflect a compensatory mechanism. However, since other basal ganglia nuclei (including striatum, entopeduncular nucleus) also express substance P receptors (Arai and Emson, 1986; Jakab and Goldman-Rakic, 1996; Mounir and Parent, 2002; Chen et al., 2003), and show electrophysiological response to substance $\mathrm{P}$ (Aosaki and Kawaguchi, 1996; Galarraga et al., 1999; Kombian et al., 2003a,b), the therapeutic effects of substance $\mathrm{P}$ administration would depend on the interaction of its actions on these nuclei. Thus, more experiments and evidence are needed before we could fully understand the functions of substance $\mathrm{P}$ in the whole basal ganglia circuit in normal conditions and movement disorders. In conclusion, the present study demonstrated a direct excitatory effect of neurokinin-1 receptor activation on pallidal neurons, which implicates a possible role of substance $\mathrm{P}$ in the treatment of Parkinson's disease.

\section{ACKNOWLEDGMENTS}

The authors wish to thank Sanofi-Aventis (Chilly-Mazarin, France) for kindly providing SR140333B. This work was supported by the Research Grants Council of Hong Kong (CUHK 4175/02M) to W.H. Yung, the grants from National Natural Science Foundation of China (30870800, 30670664), Natural Science Foundation of Shandong Province (Y2006C18), the Ministry of Education of China (200810650002) and the Bureau of Science and Technology of Qingdao (08-2-1-2-nsh) to L. Chen.

consequences following injection of the substance $\mathrm{P}$ analogue, DiMe-C7, into the rat ventral tegmental area. Pharmacol. Biochem. Behav. 37, 839-841.

Bell, M. I., Richardson, P. J., and Lee, K (1998). Characterization of the mechanism of action of tachykinins in rat striatal cholinergic interneurons. Neuroscience 87, 649-658.

Bergman, H., Feingold,A., Nini,A., Raz, A., Slovin, H., Abeles, M., and Vaadia, E. (1998). Physiological aspects of information processing in the basal ganglia of normal and parkinsonian primates. Trends Neurosci. 21, 32-38.

Betarbet, R., and Greenamyre, J. T. (2004) Regulation of dopamine receptor and neuropeptide expression in the basal ganglia of monkeys treated with MPTP. Exp. Neurol. 189, 393-403.

Boix, F., Mattioli, R.,Adams, F., Huston, J. P., and Schwarting, R. K. (1992). Effects of substance $P$ on extracellular dopamine in neostriatum and nucleus accumbens. Eur. J. Pharmacol. 216, 103-107.

Chen, L. W., Cao, R., Liu, H. L., Ju, G., and Chan, Y. S. (2003). The striatal GABAergic neurons expressing substance $P$ receptors in the basal ganglia of mice. Neuroscience 119, 919-925.

Chesselet, M. F., and Delfs, J. M. (1996). Basal ganglia and movement disorders: an update. Trends Neurosci. 19, 417-422. 
Chevalier, G., and Deniau, J. M. (1990). Disinhibition as a basic process in the expression of striatal functions. Trends Neurosci. 13, 277-280.

Cui, Q. L., Yung, W. H., Xue, Y., and Chen, L. (2007). Substance P excites globus pallidus neurons in vivo. Eur. J. Neurosci. 26, 1853-1861.

Czeh, B., Simon, M., van der Hart, M. G., Schmelting, B., Hesselink, M. B., and Fuchs, E. (2005). Chronic stress decreases the number of parvalbuminimmunoreactive interneurons in the hippocampus: prevention bytreatment with a substance $\mathrm{P}$ receptor (NK1) antagonist. Neuropsychopharmacology 30, 67-79.

De Ceballos, M. L., and LopezLozano, J. J. (1999). Subgroups of parkinsonian patients differentiated by peptidergic immunostaining of caudate nucleus biopsies. Peptides 20, 249-257.

Fernandez, A., de Ceballos, M. L., Jenner, P., and Marsden, C. D. (1994). Neurotensin, substance $P$, delta and $\mathrm{mu}$ opioid receptors are decreased in basal ganglia of Parkinson's disease patients. Neuroscience 61, 73-79.

Fernandez,A., de Ceballos, M.L., Rose, S., Jenner, P., and Marsden, C. D. (1996). Alterations in peptide levels in Parkinson's disease and incidental Lewy body disease. Brain 119 , 823-830.

Filion, M., and Tremblay, L. (1991). Abnormal spontaneous activity of globus pallidus neurons in monkeys with MPTP-induced parkinsonism. Brain Res. 547, 142-151.

Galarraga, E., Hernandez-Lopez, S., Tapia, D., Reyes, A., and Bargas, J. (1999). Action of substance P (neurokinin-1) receptor activation on rat neostriatal projection neurons. Synapse 33, 26-35.

Iwasaki, Y., Kinoshita, M., Ikeda, K., Takamiya, K., and Shiojima, T. (1989). Trophic effect of various neuropeptides on the cultured ventral spinal cord of rat embryo. Neurosci. Lett. 101, 316-320.

Jakab, R. L., and Goldman-Rakic, P. (1996). Presynaptic and postsynaptic subcellular localization of substance $P$ receptor immunoreactivity in the neostriatum of the rat and rhesus monkey (Macaca mulatta). J. Comp. Neurol. 369, 125-136.

Jenner, P. (1995). The rationale for the use of dopamine agonists in Parkinson's disease. Neurology 45, S6-S12.

Khan, S., Whelpton, R., and MichaelTitus, A. T. (1996). Evidence for modulatory effects of substance $P$ fragments (1-4) and (8-11) on endogenous dopamine outflow in rat striatal slices. Neurosci. Lett. 205, 33-36.
Kombian, S. B., Ananthalakshmi, K. V., Parvathy, S. S., and Matowe, W. C. (2003a). Dopamine and adenosine mediate substance P-induced depression of evoked IPSCs in the rat nucleus accumbens in vitro. Eur. J. Neurosci. 18, 303-311.

Kombian, S. B., Ananthalakshmi, K. V., Parvathy, S. S., and Matowe, W. C. (2003b). Substance P depresses excitatory synaptic transmission in the nucleus accumbens through dopaminergic and purinergic mechanism. J. Neurophysiol. 89, 728-737.

Krasnova, I. N., Bychkov, E. R., Lioudyno, V. I., Zubareva, O. E., and Dambinova, S. A. (2000). Intracerebroventricular administration of substance $\mathrm{P}$ increases dopamine content in the brain of 6-hydroxydopamine-lesioned rats. Neuroscience 95, 113-117.

Lastres-Becker, I., Gomez, M., De Miguel, R., Ramos, J. A., and Fernandez-Ruiz, J. (2002). Loss of cannabinoid $\mathrm{CB}(1)$ receptors in the basal ganglia in the late akinetic phase of rats with experimental Huntington's disease. Neurotox. Res. 4, 601-608.

Li, Y.W., and Guyenet, P.G. (1997).C1 and other bulbospinal cells of the RVLM in neonatal rats. Am. J. Physiol. 273, R805-R813.

Liu, R., Ding, Y., and Aghajanian G. K. (2002). Beurokinins activate local glutamatergic inputs to serotonergic neurons of the dorsal raphe nucleus. Neuropsychopharmacology 27, 329-340.

Magill, P. J., Bolam, J. P., and Bevan, M. D. (2001). Dopamine regulates the impact of the cerebral cortex on the subthalamic nucleus-globus pallidus network. Neuroscience 106, 313-330.

Mantyh, P.W., Hunt, S. P., and Maggio, J. E. (1984). Substance P receptors: localization by light microscopic autoradiography in rat brain using $[3 \mathrm{H}] \mathrm{SP}$ as the radioligand. Brain Res. 307, 147-165.

Martorana, A., Fusco, F. R., D’Angelo, V., Sancesario, G., and Bernardi, G. (2003). Enkephalin, neurotensin, and substance $\mathrm{P}$ immunoreactivite neurones of the rat GP following 6-hydroxydopamine lesion of the substantia nigra. Exp. Neurol. 183, 311-319.

Mattioli, R., Schwarting, R. K., and Huston, J. P. (1992). Recovery from unilateral 6-hydroxydopamine lesion of substantia nigra promoted by the neurotachykinin substance P 1-11. Neuroscience 48, 595-605.

Maubach, K. A., Martin, K., Smith, D. W., Hewson, L., Frankshun, R. A., Harrison, T., and Seabrook, G. R.
(2001). Substance P stimulates inhibitory synaptic transmission in the guinea pig basolateral amygdale in vitro. Neuropharmacology 40, 806-817.

Minabe, Y., Emori, K., Toor, A. Stutzmann, G. E., and Ashby, C. R. Jr (1996). The effect of the acute and chronic administration of CP 96,345, a selective neurokinin 1 receptor antagonist, on midbrain dopamine neurons in the rat: a single unit, extracellular recording study. Synapse 22 , 35-45.

Mitrovic, I., and Napier, T. C. (1998). Substance $\mathrm{P}$ attenuates and DAMGO potentiates amygdala glutamatergic neurotransmission within the ventral pallidum. Brain Res. 792, 193-206.

Monteau, R., Ptak, K., Broquere, N., and Hilaire, G. (1996). Tachykinins and central respiratory activity: an in vitro study on the newborn rat. Eur. J. Pharmacol. 314, 41-50.

Mounir, S., and Parent, A. (2002). The expression of neurokinin-1 receptor at striatal and pallidal levels in normal human brain. Neurosci. Res. 44 71-81.

Napier, T. C., Mitrovic, I., Churchill, L. Klitenick, M. A., Lu, X. Y., and Kalivas, P. W. (1995). Substance P in the ventral pallidum: projection from the ventral striatum, and electrophysiological and behavioral consequences of pallidal substance P. Neuroscience 69, 59-70.

Nikolaus, S., Huston, J. P., Korber, B., Thiel, C., and Schwarting, R. K. (1997). Pretreatment with neurokinin substance $\mathrm{P}$ but not with cholecystokinin-8S can alleviate functional deficits of partial nigrostriatal 6hydroxydopamine lesion. Peptides 18, 1161-1168.

Nikolaus, S., Huston, J. P., and Schwarting, R. K. (1999). Pretreatment with fragments of substance-P or with cholecystokinin differentially affects recovery from sub-total nigrostriatal 6-hydroxydopamine lesion. Neural Plast. 6, 77-89.

Norris, S. K., Boden, P. R., and Woodruff, G. N. (1993). Agonists selective for tachykinin NK1 and NK3 receptors excite subpopulations of neurons in the rat medial habenula nucleus in vitro. Eur. J. Pharmacol. 234, 223-228.

Perez-Otano, I., Luquin, M. R., Oset, C., Herrero, M. T., Kupsch, A., Oertel, W. Obeso, J. A., and Del Rio, J. (1995). Neurotoxicity induced by prenatal exposure to MPTP on the monoaminergic and peptidergic systems of the marmoset brain. Exp. Neurol. 131, 108-113.

Pezzoli, G., Panerai, A. E., Di Giulio, A., Longo, A., Passerini, D., and Carenzi, A. (1984). Methionine-enkephalin, substance $\mathrm{P}$, and homovanillic acid in the CSF of parkinsonian patients. Neurology 34, 516-519.

Plenz, D., and Kital, S. T. (1999). A basal ganglia pacemaker formed by the subthalamic nucleus and external globus pallidus. Nature 400, 677-682.

Preston, Z., Lee, K., Widdowson, L., Richardson, P. J., and Pinnock, R. D. (2000). Tachykinins increase $[3 \mathrm{H}]$ acetylcholine release in mouse striatum through multiple receptor subtypes. Neuroscience 95, 367-376.

Ptak, K., Konrad, M., Di Pasquale, E., Tell, F., Hilaire, G., and Monteau, R. (2000). Cellular and synaptic effect of substance $\mathrm{P}$ on neonatal phrenic motoneurons. Eur. J. Neurosci. 12, 126-138.

Reid, M. S., Herrera-Marschitz, M., Hokfelt, T., Ohlin, M., Valentino, K. L., and Ungerstedt, U. (1990). Effects of intranigral substance $\mathrm{P}$ and neurokinin A on striatal dopamine release-I. Interactions with substance $\mathrm{P}$ antagonists. Neuroscience 36, 643-658.

Rioux, L., and Joyce, J. N. (1993). Substance P receptors are differentially affected in Parkinson's and Alzheimer's disease. J. Neural Transm. Park. Dis. Dement. Sect. 6, 199-210.

Rosler, N., Wichart, I., and Jellinger, K. A. (2001). Ex vivo lumbar and post mortem ventricular cerebrospinal fluid substance P-immunoreactivity in Alzheimer's disease patients. Neurosci. Lett. 299, 117-120.

Salin, P., Hajji, M. D., and Kerkerianle Goff, L. (1996). Bilateral 6-hydroxydopamine-induced lesion of the nigrostriatal dopamine pathway reproduces the effects of unilateral lesion on substance $\mathrm{P}$ but not on enkephalin expression in rat basal ganglia. Eur. J. Neurosci. 8, 1746-1757.

Sanberg, P. R., Emerich, D. F., Aebischer, P., Amisetti, S. M., Ouellette, W., Koutouzis, T. K., Cahill, D. W., and Norman, A. B. (1993). Substance P containing polymer implants protect against striatal excitotoxicity. Brain Res. 628, 327-329.

Santarelli, L., and Saxe, M. D. (2003). Substance $P$ antagonists: meet the new drugs, same as the old drugs? Insights from transgenic animal models. CNS Spectr. 8, 589-596.

Shen, K. Z., and North, R. A. (1992). Substance P opens cation channels and closes potassium channels in rat locus coeruleus neurons. Neuroscience 50, 345-353.

Shirakawa, T., and Moore, R. Y. (1994). Responses of rat suprachiasmatic nucleus neurons to substance $\mathrm{P}$ and glutamate in vitro. Brain Res. 642, 213-220. 
Stacey, A. E., Woodhall, G. L., and Jones, R. S. (2002a). Activation of neurokinin-1 receptors promotes GABA release at synapses in the rat entorhinal cortex. Neuroscience 115, 575-586.

Stacey, A. E., Woodhall, G. L., and Jones, R. S. G. (2002b). Neurokininreceptor-medicated depolarization of cortical neurons elicits an increase in glutamate release at excitatory synapses. Eur. J. Neurosci. 16, 1896-1906.

Stanfield, P. R., Nakajima, Y., and Yamaguchi, K. (1985). Substance P raises neuronal membrane excitability by reducing inward rectification. Nature 315, 498-501.

Tang, F., Cheung, A., and VaccaGalloway, L. L. (1990). Measurement of neuropeptides in the brain and spinal cord of Wobbler mouse: a model for motoneuron disease. Brain Res. 518, 329-333.

Taylor, M. D., De Ceballos, M.L., Rose, S., Jenner, P., and Marsden, C. D. (1992). Effects of a unilateral 6-hydroxydopamine lesion and prolonged L-3,4-dihydroxyphenylalanine treatment on peptidergic systems in rat basal ganglia. Eur. J. Pharmacol. 219, 183-192.

Vacca-Galloway,L.L., andSteinberger, C. C. (1986). Substance P neurons sprout in the cervical spinal cord of the wobbler mouse: a model for motoneuron disease. J. Neurosci. Res. 16, 657-670.

Velumian,A.A., Zhang, L., Pennefather, P., and Carlen, P. L. (1997). Reversible inhibition of IK, IAHP, Ih and ICa currents by internally applied gluconate in rat hippocampal pyramidal neurones. Pflugers Arch. 433, 343-350.

Vergnano, A. M., Salio, C., and Merighi, A. (2004).NK1 receptor activation leads to enhancement of inhibitory neurotransmission in spinal substantia gelatinosa neurons of mouse. Pain 112, 37-47.

Wang, X., and Robertson, D. (1997). Effects of bioamines and peptides on neurones in the ventral nucleus of trapezoid body and rostral periolivary regions of the rat superior olivary complex: an in vitro investigation. Hear. Res. 106, 20-28.

Wang, X., and Robertson, D. (1998). Substance P-induced inward current in identified auditory efferent neurons in rat brain stem slices. J. Neurophysiol. 80, 218-229.

Wichmann, T., and DeLong, M. R. (1996). Functional and pathophysiological models of the basal ganglia. Curr. Opin. Neurobiol. 6, 751-758.

Yasuda, K., Robinson, D. M., Selvaratnam, S. R., Walsh, C. W., McMorland, A. J., and Funk, G.D. (2001). Modulation of hypoglossal motoneuron excitability by NK1 receptor activation in neonatal mice in vitro. J. Physiol. 534, 447-464.

Yung, K. K., Tang, F., Fielding, R., Du, Y. H., and Vacca-Galloway, L. L. (1992). Alteration in the levels of thyrotropin releasing hormone, substance $\mathrm{P}$ and enkephalins in the spinal cord, brainstem, hypothalamus and midbrain of the Wobbler mouse at different stages of the motoneuron disease. Neuroscience 50, 209-222.
Conflict of Interest Statement: The authors declare that the research was conducted in the absence of any commercial or financial relationships that could be construed as a potential conflict of interest.

Received: 29 June 2009; paper pending published: 13 July 2009; accepted: 01 October 2009; published online: 26 October 2009.

Citation: Chen L, Cui Q-L and Yung W-H (2009) Neurokinin-1 receptor activation in globus pallidus. Front. Neurosci. 3:58. doi: 10.3389/neuro.23.002.2009

This article was submitted to Frontiers in Neuropharmacology, a specialty of Frontiers in Neuroscience.

Copyright (c) 2009 Chen, Cui and Yung. This is an open-access article subject to an exclusive license agreement between the authors and the Frontiers Research Foundation, which permits unrestricted use, distribution, and reproduction in any medium, provided the original authors and source are credited. 